\title{
Urgensi Bahasa Inggris Dikembangkan Sejak Anak Usia Dini
}

\author{
$\mathrm{Na}^{\prime} \mathrm{imah}^{1}{ }^{凶}$ \\ Pendidikan Islam Anak Usia Dini, Universitas Islam Negeri Sunan Kalijaga Yogyakarta, \\ Indonesia \\ DOI: $\underline{10.31004 / o b s e s i . v 6 i 4.1916}$
}

\begin{abstract}
Abstrak
Saat ini, anak usia dini dihadapkan dengan media digital yang berbasis bahasa Inggris. Sehingga perlu strategi agar kemampuan bahasa Inggris anak usia dini berkembang lebih optimal. Metode penelitian dalam hal ini adalah deskriptif kualitatif, subjek penelitian berjumlah 14 anak dari kelas A1, 12 anak dari A2 dan 1 guru bahasa inggris di RA Nurul Falah Cirebon. Pengumpulan data dilakukan dengan observasi, wawancara, dan dokumentasi. Hasil penelitian di RA Nurul Falah Cirebon mengembangkan pembelajaran bahasa inggris dalam proses belajar mengajar dan memberikan stimulasi pada anak didik sejak dini di sekolah. Strategi pembelajaran bahasa inggris dengan cara bernyanyi, bermain, tanya jawab, dan memanfaatkan barang-barang tersedia di kelas. Melalui strategi tersebut, anak berhasil mengembangkan kemampuan bahasa Inggris dengan baik.
\end{abstract}

Kata Kunci: strategi; bahasa inggris; anak usia dini.

\begin{abstract}
Today, early childhood is faced with English-based digital media. So it needs a strategy so that early childhood English skills develop. This type of research is qualitative descriptive, the study subjects amounted to 14 children from class A and 12 children from B and 1 English teacher at RA Nurul Falah Cirebon. Data collection is done with observations, interviews, and documentation. The results of research at RA Nurul Falah Cirebon develop English language learning in the teaching and learning process and provide stimulation to students early on in school. English learning strategies by singing, playing, Q\&A, and utilizing items are available in the classroom. Through this strategy, children successfully develop english skills well.
\end{abstract}

Keywords: strategy; english; early childhood.

Copyright (c) 2021 Nama Penulis1,2 dst.

$\triangle$ Corresponding author:

Email Address : naimah@uin-suka.ac.id (Yogyakarta, Indonesia)

Received 3 November 2021, Accepted 23 January 2022, Published 24 january 2022

\section{PENDAHULUAN}

Perkembangan bahasa pada manusia sangat penting, dan diajarkan ketika masih usia dini sehingga dapat mampu mengucapkan perkosa-kata hingga kalimat yang fasih serta di mengerti oleh lawan bicara (Sabaniah et al., 2021). Perkembangan bahasa proses yang mengontrol otak kiri manusia dalam bahasa, dan berbicara yang sangat penting di miliki oleh manusia (Pagarwati \& Rohman, 2020). Bahasa adalah alat komunikasi yang penting harus 
mampu dimiliki, dan menjadi kelebihan bagi anak jika mampu berkomunikasi dengan lancer. Jika seseorang kesulitan dalam berkomunikasi dengan bahasa yang kurang dimiliki akan kesulitan pula dalam bersosialisasi dengan lingkungan sekitar.

Bahasa Inggris ialah bahasa asing di Indonesia namun sangat penting diajarkan pada anak sejak dini mungkin sebab bahasa inggris ialah bahasa internasional yang di pakai penjuru dunia dapat mempermudah berkomunikasi ketika berada di luar Indonesia sebagai komunikasi yang utama (Oktaria \& Putra, 2020). Kini banyak sekali sekolah formal anak sejak dini sudah menerapkan dalam stimulasi untuk memperkenalkan pembelajaran pada anak usia dini dapat di mulai dari kosa kata, dan buah-buahan maupun abjad serta angka. (Pangastuti et al., 2020). Selain itu, dapat diajarkan melalui gambar dengan kosa kata ataupun benda dengan Bahasa Inggris dapat pula menggunakan melalui video animasi yang menggunakan Bahasa Inggris.

Bahasa Inggris sebagai bahasa internasional yang sudah diakui oleh dunia, dan semua orang berkunjung ke negara asing bahasa yang digunakan untuk berkomunikasi dengan orang domestic menggunakan Bahasa Inggris yang sangat penting dimiliki oleh setiap orang (Qadafi, 2020). Memberikan didikan pada anak sejak dini secara rutin akan berdampak pada tumbuh kembang anak dalam berkomunikasi dengan lawan bicara walaupun tidak akan mampu berkomunikasi menggunakan Bahasa Inggris perkalimat namun setidaknya perkosa kata, dan mengajarkan dengan rutin maka akan terlihat hasil. Mengajarkan Bahasa Inggris pada anak usia dini akan berbeda ketika mengajarkan pada anak tingkat SD hingga SMA, anak usia dini perlu diberikan pembelajaran yang menarik, dan menyenangkan sehingga anak akan mampu tertarik dengan hal yang baru. Selain itu, konsentrasi anak usia dini hanya berlaku 5-10 menit sehingga perlu disatukan stimulasi dengan menarik sehingga anak tidak merasakan cepat jenuh pada saat proses belajar mengajar dilakukan (Ulfa \& Na'imah, 2020).

Mengenalkan Bahasa Inggris pada anak sejak dini memiliki pandangan berbeda sebab menurut Penfield dalam teori mekanisme otak (theory of brain mechanism) usia dini ialah fase yang tepat untuk di stimulasi bahasa lain selain bahasa ibu (bahasa pertama) (Dewi, 2020). Sebab pada usia dini otak anak sedang baik menerima rangsangan maka dari itu sangat tepat jika diberikan berbagai macam stimulasi untuk mengasah kemampuan bahasa maupun kemampuan aspek perkembangan anak lainnya (Umi et al., 2020). Selain itu, memiliki pendapat buruk pada anak sejak dini sudah diajarkan Bahasa Inggris ialah anak usia dini masa anak sedang bermain, dan akan memberatkan anak jika diberikan stimulasi mengenalkan Bahasa Inggris ataupun bahasa asing lainnya (Satrianingrum et al., 2021). Adanya pro kontra jika anak usia dini sangat tepat diberikan stimulasi namun sebagai orang tua maupun guru perlu membuat strategi untuk mengembangkan Bahasa Inggris pada anak sejak dini sehingga anak tidak kehilangan waktu bermain, dan tidak memberatkan pada otak anak bahkan bagus jika anak diberikan stimulasi yang baik dengan cara yang tepat pula (Huda et al., 2020).

Pendidikan formal bagi anak diawali dengan PAUD sehingga dapat memberikan stimulasi, dan pendidikan terbaik maupun tepat bagi anak sejak dini (Zahroh \& Na'imah, 2020). PAUD mampu membantu tahapan perkembangan anak sehingga mampu mengasah semua kemampuan aspek perkembangan anak sejak dini. PAUD menyediakan fasilitas untuk anak didik baik berupa sarana prasarana, hingga alat permainan edukatif serta area permainan yang disediakan lapangan sekolah untuk melatih aspek perkembangan anak (Anugrahana, 2020). Selain itu, guru di sekolah harus mampu mengawasi anak ketika anak bermain di area sekolah sebab anak usia dini tinggi sekali rasa ingin tahu serta akan menjelajahi wahana permainan yang tersedia di sekolah (Nurul Fadlilah et al., 2021).

Orang tua maupun guru dapat menggunakan beberapa cara untuk mengembangkan kemampuan Bahasa Inggris pada anak sejak dini (Mufaziah \& Fauziah, 2020). Maka dari itu pentingnya anak sejak dini diberikan stimulasi dengan tepat namun tidak memaksakan kemampuan pada anak sebab kemampuan anak akan berbeda dengan anak lainnya namun yang perlu diperhatikan memberikan stimulasi dengan telaten, dan sesering mungkin sehingga dapat menempel pada otak anak kemudian anak mampu mempraktekkan dengan 
sendirinya sebab sudah terbiasa dilakukan selama di rumah, dan di rumah (Hignasari, 2020). Pembelajaran Bahasa Inggris tidak melulu di lakukan dalam pendidikan formal, orang tua pun dapat memberikan stimulasi (Umi et al., 2020). Orang tua harus mampu menstimulasi dengan rutin pada anak sehingga anak akan mampu mencontohkan pada kehidupan seharihari hingga dewasa (Mufaziah \& Fauziah, 2021).

Orang tua memiliki tanggung jawab untuk memberikan didikan sudah mulai memahami betapa pentingnya anak sekolah formal sejak dini, dan orang tua mengetahui jika anak sekolah di lembaga formal akan diberikan stimulasi yang tepat oleh guru selama anak di sekolah (Wiresti, 2020). Usia anak yang sekolah di PAUD diantaranya 4-6 tahun waktu yang tepat jika diberikan stimulasi oleh guru di sekolah, dan anak akan mampu bersosialisasi dengan teman-teman sebaya nya selama di sekolah. Mengapa pentingnya anak diberikan pendidikan formal dikenalkan dengan lingkungan sekitar (Rozie et al., 2019). Anak usia dini sedang dalam fase golden age dimana masa keemasan anak yang tidak akan terulang hingga dua kali maka guru harus merancang pendidikan yang terbaik serta tepat untuk anak hingga dewasa (Mutiani \& Suyadi, 2020).

Guru penting memberikan pemahaman menggunakan Bahasa Inggris pada anak dalam memperkenalkan bahasa guna perkembangan kemampuan bahasa anak usia dini (Aisya et al., 2020). Sejak anak perlu dilakukan konkret sehingga anak dapat memahami yang dimaksud dengan diartikan dalam Bahasa Indonesia (Afnida \& Suparno, 2020). Guru dalam memilih metode akan sangat berpengaruh pada tujuan yang dicapai oleh anak didik di sekolah. Anak memiliki fase tertentu dalam usia untuk itu perlu diberikan stimulasi sehingga mampu mengoptimalkan tumbuh kembang sejak dini, dan diberikan secara rutin dengan begitu akan mudah diberikan pengenalan Bahasa inggris sejak dini sehingga akan bermanfaat ketika anak tumbuh dewasa untuk mampu bersaing dengan dunia.

Guru pun perlu memilih untuk strategi belajar akan terlihat menarik akan mudah ketika anak dalam menerima bahan ajar pada anak di kelas (Candra, 2018). Guru yang kreatif akan berdampak pada berjalan nya pembelajaran maupun memberikan stimulasi pada anak dengan mengajarkan Bahasa Inggris sedikit demi sedikit pada anak usia dini selama di kelas, dan di bantu dengan media maupun alat permainan edukatif sebagai penunjang memberikan pembelajaran Bahasa Inggris (Tiolina Siregar \& Tarigan, 2021). Adapun cara untuk mengoptimalkan kemampuan bahasa anak dengan cara yang tepat jika tidak akan berdampak pada tidak optimal anak belajar dengan menyerap ilmu dari guru, dan guru akan mempengaruhi anak mampu mengerti ataupun tidak (Umi et al., 2020).

Bermain bagi anak usia dini sangatlah penting bagi kegiatan mereka bahkan dunia anak hanya bermain, orang tua maupun guru perlu menyadari bahwa anak dunianya adalah bermain maka dari itu berikan permainan yang mengandung pembelajaran. Belajar dikemas dengan bermain namun masih membuat anak senang, nyaman, dan menciptakan suasana rumah yang menyenangkan sehingga anak nyaman berada di lingkungan rumah untuk bermain, belajar serta bercengkerama dengan orang tua maupun anggota keluarga lainnya. Pendidikan anak dalam keluarga sangat penting maka orang tua harus menyadari betapa pentingnya pendidikan sebagai pondasi yang utama bagi anak sejak dini sehingga anak tumbuh dewasa menjadi sosok yang hangat dekat dengan orang tua serta anggota keluarga lainnya. Kehangatan keluarga di bangun saat anak berada di usia dini sebab tidak mudah membangun kehangatan keluarga, dan anak akan merasakan kehangatan keluarga mampu memberikan peran positif bagi tumbuh kembang anak. Anak akan menjadi pribadi yang menyenangkan, dekat dengan keluarga tidak akan membatasi anak dengan orang tua karena itu yang menjadi penting sehingga orang tua mampu mengawasi anak ketika tumbuh dewasa dengan menjadikan anak sahabat orang tua. Sebab kedekatan emosional sudah dibentuk, dan dijalin saat anak berada di usia dini hingga anak tumbuh dewasa. Banyak yang dilupakan oleh beberapa orang tua untuk mendekatkan anak dengan orang tua sejak dini sehingga ketika tumbuh dewasa anak mempunyai ikatan batin erat. 


\section{METODOLOGI}

Riset ini memakai metode kualitatif deskriptif. Subjek dalam penelitian ini yakni guru, anak didik kelas A yang berjumlah 14 anak, dan anak didik kelas B yang berjumlah 12 anak RA Nurul Falah Cirebon. Adapun tahapan penelitian ini dengan melakukan pengumpulan data, kemudian reduksi data, penyajian data, dan menarik kesimpulan. Tahapan penelitian diilustrasikan pada bagan 1 .

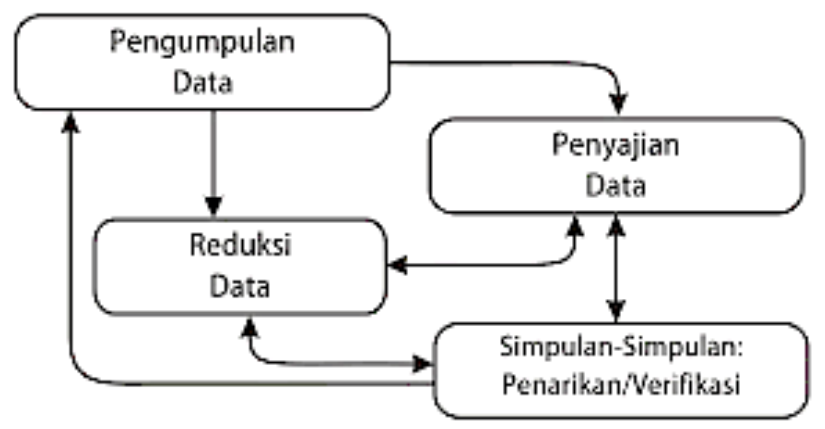

Bagan 1. Tahapan Penelitian

Tahapan pertama yakni pengumpulan data melalui beberapa metode yakni wawancara, observasi, dan dokumentasi. Kemudian, Teknik pengumpulan data dalam penelitian ini menggunakan observasi langsung ke RA Nurul Falah Cirebon untuk melihat keadaan pada anak didik dalam belajar, melihat lingkungan sekolah, melakukan wawancara dengan kepala sekolah maupun guru wali kelas A serta B, dan dokumentasi di RA Nurul Falah Cirebon. Peneliti melihat langsung dalam guru memberikan pemahaman, pengajaran hingga stimulasi pada anak didik. Pengajaran di lakukan secara rutin oleh guru, dan diselingi dengan memberikan stimulasi Bahasa Inggris menggunakan media yang sudah disediakan oleh guru, seperti video animasi, gambar-gambar, gerak dan lagu dan buku-buku berbasis bahasa Inggris. Sarana prasarana sekolah akan sangat berpengaruh pada optimal pembelajaran anak didik sebab jika hanya memberikan pemahaman tanpa media akan kurang optimal maka pihak sekolah menyediakan semua peralatan yang akan dibutuhkan pengajaran di sekolah. Kemudian analisis data dengan menggunakan triangulasi dengan mereduksi data dan melakukan penyajian data. Serta tahapan terakhir yakni dengan menarik kesimpulan atau verifikasi hasil akhir data yang sudah dikumpulkan.

\section{HASIL DAN PEMBAHASAN Hasil Penelitian}

Hasil observasi mendapatkan data jika mengembangkan Bahasa Inggris pada anak didik di RA Nurul Falah Cirebon dengan cara membiasakan anak untuk menyebutkan kosa kata benda ataupun yang sekitaran sekolah sehingga anak akan terbiasa namun guru harus menerapkan pembiasaan terlebih dahulu pada anak didik. Dalam memberikan pengenalan Bahasa Inggris pada anak didik guru di RA Nurul Falah Cirebon memiliki strategi pembelajaran yang dipergunakan dalam proses belajar mengajar seperti memberikan media gambar benda maupun makanan dalam Bahasa Inggris, menggunakan video pembelajaran menggunakan Bahasa Inggris, melakukan pelafalan perkosa kata menggunakan Bahasa Inggris, dapat bernyanyi dengan Bahasa Inggris dengan anak selama proses belajar mengajar di kelas, dan bermain game menggunakan Bahasa Inggris sehingga dengan begitu pembelajaran akan menempel di otak anak usia dini. Sebab otak anak usia dini sangat baik jika diberikan stimulasi yang tepat menggunakan cara, dan bertahap tidak memaksakan kehendak anak ataupun terus menerus. Selayaknya pembelajaran bagi anak didik harus bertahap, rutin serta pembiasaan pada anak usia di sekolah maupun di kelas. Guru 
memberikan pembelajaran, dan menstimulasi Bahasa Inggris pada anak didik sesuai dengan kebijakan sekolah serta tema pembelajaran yang tiap minggu nya berbeda.

Didukung oleh hasil wawancara dengan kepala sekolah yang menyebutkan menerapkan pola strategi pembelajaran yang berbasis Bahasa Inggris pada anak usia dini sangat tepat diberikan dalam masa golden age yang hanya datang sekali seumur hidup, dan pihak sekolah akan berdedikasi untuk memberikan yang terbaik untuk anak didik di RA Nurul Falah Cirebon. Pembelajaran pun dilakukan pembelajaran yang menyenangkan akan memberikan suasana yang berbeda sehingga anak tidak merasakan tertekan dalam diberikan bahan ajar oleh guru, dan guru menerapkan happy playing and educating belajar bermain yang menyenangkan untuk anak sehingga anak akan merasakan rasa senang dalam mengikuti pembelajaran oleh setiap guru. Happy playing and educating ialah proses pembelajaran yang menerapkan bermain sambil belajar yang menyenangkan. Seperti bernyanyi bahasa Inggris mengenai nama-nama hewan, tumbuhan dan sebagainya. Kondisi kegiatan english learning digambarkan pada gambar 1 .

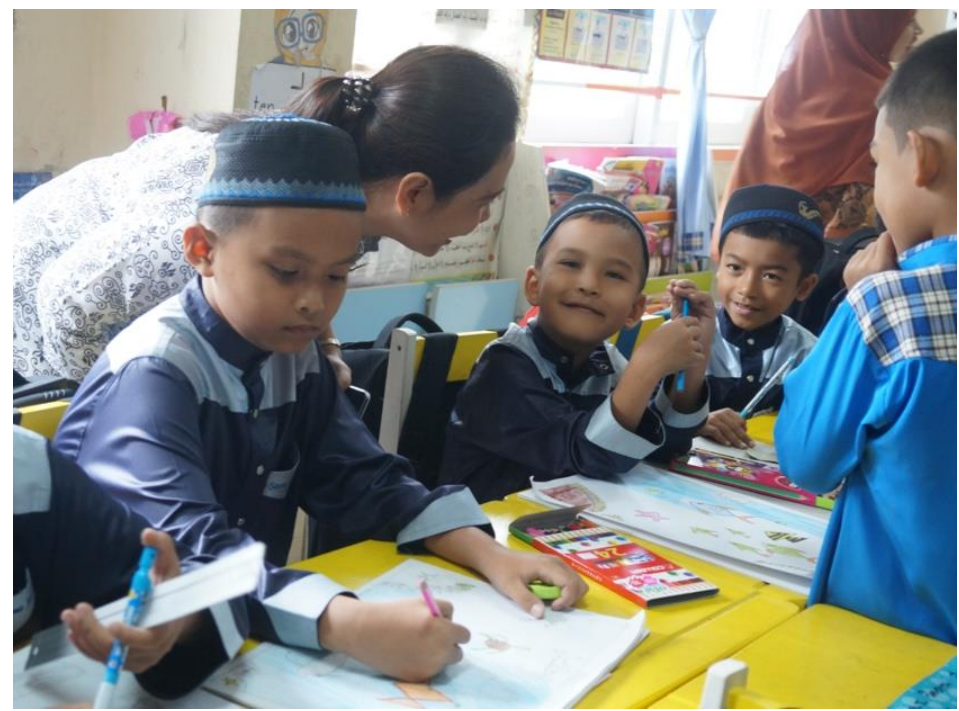

Gambar 1. English Learning Activities

Selain itu, sebelum guru memberikan bahan ajar pada anak didik di dalam kelas dilakukan berdiskusi dengan guru lainnya beserta dengan kepala sekolah untuk membicarakan strategi belajar seperti apa yang tepat untuk anak didik sehingga stimulasi yang diberikan dalam Bahasa Inggris optimal untuk anak didik. Guru memberikan pembelajaran dapat membantu kosa kata anak dalam Bahasa Indonesia yang belum sempurna, dan belajar per kosa kata dalam Bahasa Inggris hingga anak nantinya akan mampu berkomunikasi walaupun masih terbata-tata namun hal yang wajar seperti itu sebab untuk mengenalkan Bahasa Inggris pada anak sejak dini sudah bagus namun untuk berkomunikasi dengan lancer membutuhkan waktu, dan proses yang cukup lama. Guru pun harus memberikan stimulasi yang rutin pada anak didik selama proses belajar mengajar berlangsung sehingga anak akan terbiasa sebab sudah menjadi pembiasaan guru dalam melakukan proses belajar di kelas setiap harinya dengan memberikan media pembelajaran juga sehingga akan memudahkan anak mencerna ilmu dari guru tersebut.

\section{Pembahasan}

Hasil riset ini membuktikan bahwa pola pengajaran berbahasa Inggris yang dilakukan oleh guru melalui strategi pembelajaran seperti bernyanyi, menampilkan video animasi, mewarnai, pengenalan gambar-gambar dengan menggunakan bahasa Inggris. Senada dengan hasil penelitian sebelumnya mengungkapkan bahwa strategi dalam mengembangkan Bahasa Inggris mengacu pola pengajaran di kelas (Hasanah \& Ulya, 2020). Pola pengajaran seperti ini, 
memberikan kesempatan bagi anak secara tidak sadar terbiasa menggunakan bahasa Inggris dalam kegiatan sehari-hari. Sehingga kemampuan bahasa Inggris anak lebih terasah dan berkembang. Kemampuan bahasa Inggris anak yang baik dapat memudahkan anak dalam menghadapi kondisi teknologi yang sebagian besar banyak menggunakan bahasa Inggris. Komunikasi mudah dan sudah universal memerlukan basic kemampuan berbahasa Inggris. Sejak anak usia dinilah perlu dimulai belajar dan difasilitasi oleh orangtua dan guru di sekolah.

Anak mampu mengembangkan kemampuan bahasa Inggris melalui strategi pembelajaran dengan mengenalkan perkosa-kata sesuai tema misalnya benda, hewan, tumbuhan, maupun makanan menggunakan Bahasa Inggris. Tugas guru ialah membantu anak didik untuk mampu paham akan bahan ajar yang telah disampaikan oleh guru namun memberikan penjelasan pada anak usia dini harus mudah dipahami dalam segi penyampaian, dan menggunakan bahasa yang tidak bertele-tele sehingga anak mampu mengerti akan pemebelajaran tsrsebut (Windarsih et al., 2017). Guru harus mampu memberikan rasa perhatian pada anak didik seperti motivasi dalam belajar seperti anak terlihat kesulitan dalam belajar namun guru sedia membantu namun dengan memberikan semangat pada anak (Hewi \& Asnawati, 2020). Memberikan semangat pada anak sejak dini sangat bagus diterapkan sejak dini sebab anak akan merasakan ada yang perhatian pada dirinya sehingga anak akan kembali semangat untuk belajar. Sangat penting mendapatkan dukungan moril oleh orang tua terlebih dukungan dari orang tua sebab anak sangat membutuhkan dorongan dari orang terdekat, dan merasa di cintai oleh orang terdekat anak. Selain itu, anak akan menjadi pribadi yang hangat sebab tumbuh dari keluarga, dan lingkungan yang hangat pula dengan memberikan dorongan berupa semangat serta motivasi yang sangat berarti bagi hidup anak.

Belajar mengajar di kelas adalah suatu kegiatan rutin yang dilakukan oleh guru sehingga perlu memperhatikan anak didik dalam semua aspek perkembangan anak sehingga dapat di awasi, dan ketika rapat dengan orang tua dapat memberitahukan perkembangan aspek tumbuh kembang anak apakah naik, stabil ataupun menurun sehingga akan ada komunikasi baik antara orang tua dengan guru (Hasfira \& Marelda, 2021). Jika anak di stimulasi oleh guru di sekolah dalam melatih keterampilan baru seperti belajar Bahasa Inggris di sekolah tampilkan dengan cara menarik sehingga dapat mendorong rasa ingin tahu anak sebab hakikat anak usia dini ialah tertarik dengan hal yang baru, dan rasa ingin tahu yang tinggi (Kurniawan \& Hermawan, 2016). Maka perlu manfaatkan kesempatan emas, dan baik dalam hakikat anak usia dini untuk diberikan stimulasi dnegan baik serta didik dengan tepat oleh guru di sekolah. Selain itu, guru dapat memberikan arahan pada anak untuk memiliki rasa sopan santun pada usia di atas anak seperti pada orang tuan, anggota keluarga, guru ataupun dengan lingkungan sekitar. Pendidikan dasar untuk anak sejak dini sangat penting diterapkan, dan jangan luput untuk memberikan pendidikan moral pada anak sejak dini.

Guru memiliki peran sangat penting bagi anak untuk memberikan pendidikan, dan mengasah kemampuan anak dalam semua aspek perkembangan anak (Wakhidah \& Umah, 2020). Kegiatan anak dalam kelas maupun lingkungan sekolah dalam pengawasan guru maka dari itu sarana dan prasarana sekolah harus ramah untuk anak usia dini yang artinya tidak membahayakan untuk anak baik fisik ataupun berupa asupan makanan. Kegiatan proses belajar mengajar di kelas dapat di susun terlebih dahulu oleh guru dalam RPPH, serta media yang cocok diberikan pada anak dalam suatu tema pembelajaran. Selain itu, guru harus mampu menciptakan suasana belajar yang menyenangkan untuk anak dalam kelas, dan guru mampu memberikan pembelajaran yang aktif, kreatif, dan inovatif dalam merangsang semua aspek perkembangan anak termasuk kemampuan anak dalam Bahasa Inggris. Untuk memberikan stimulasi pembelajaran Bahasa Inggris bagi anak usia dini perlu diberikan secara rutin, dan sesuai porsi untuk anak usia dini.

Dunia anak salah satunya ialah bermain maka dari itu guru perlu mengetahui dunia anak ialah bermain sehingga memberikan pembelajaran ataupun stimulasi di campurkan dalam bermain sehingga anak akan nyaman belajar, dan mengembangkan Bahasa Inggris bagi 
anak sejak dini. Guru pun harus mengetahui strategi yang tepat bagi anak usia dini dalam proses belajar mengajar dengan berbagai cara yang inovatif. Dapat diberikan menggunakan alat permainan edukatif yang akan bermakna bagi tumbuh kembang anak sejak dini. Selain itu, hal utama menciptakan rasa berani tampil di depan kelas bagi anak sejak dini sehingga anak akan mampu menyebutkan kosa kata dalam Bahasa Inggris di depan kelas sebab sangat penting rasa percaya diri anak di tumbuhkan sejak dini sehingga anak akan berani tampil di depan dalam hadapan teman-teman kelas, dan akan memiliki nilai positif lainnya untuk anak hingga anak tumbuh dewasa.

\section{SIMPULAN}

Strategi guru dalam menstimulasi dan mengembangkan Bahasa Inggris pada anak didik di RA Nurul Falah Cirebon mengalami peningkatan sebab guru memiliki cara yang tepat sehingga anak mampu mengenal Bahasa Inggris. Anak mampu mengembangkan kemampuan bahasa Inggris. Strategi pembelajaran dengan mengenalkan per kosa kata sesuai tema misalnya benda, hewan, tumbuhan, maupun makanan menggunakan Bahasa Inggris. Pengenalan pembelajaran sangat penting diterapkan oleh guru dengan rutin namun tidak memaksakan ataupun memberatkan kemampuan anak yang harus bisa sebab kemampuan anak dengan anak lainnya berbeda, disinilah peran guru sangat penting serta utama untuk memberikan pengajaran, dan stimulasi dalam mengembangkan Bahasa Inggris untuk anak usia dini.

\section{UCAPAN TERIMA KASIH}

Terima kasih pada Universitas Islam Negeri Sunan Kalijaga Yogyakarta.

\section{DAFTAR PUSTAKA}

Afnida, M., \& Suparno, S. (2020). Literasi dalam Pendidikan Anak Usia Dini: Persepsi dan Praktik Guru di Prasekolah Aceh. Jurnal Obsesi : Jurnal Pendidikan Anak Usia Dini, 4(2), 971. https:// doi.org/10.31004/obsesi.v4i2.480

Aisya, N., Amelia, N., Tinggi, S., Tarbiyah, I., Hikmah, A., Tinggi, T., \& Utara, S. (2020). Alat Permainan Edukatif Dalam Mengembangkan Kreativitas Musik Anakdi Pendidikan Anak Usia Dini ' Aisyiyah Terpadu Gantiwarno menstimulus anak dalam mengenal Permainan baik bentuk dan menumbuhkan bahasa memainkannya ( Syamsuardi ,. 3(2). https://doi.org/10.31851/pernik.v3i2.4838

Anugrahana, A. (2020). Hambatan, Solusi dan Harapan: Pembelajaran Daring Selama Masa Pandemi Covid-19 Oleh Guru Sekolah Dasar. Scholaria: Jurnal Pendidikan Dan Kebudayaan, 10(3), 282-289. https:// doi.org/10.24246/j.js.2020.v10.i3.p282-289

Candra, S. (2018). Pelaksanaan Parenting Bagi Orang Tua Sibuk Dan Pengaruhnya Bagi Perkembangan Anak Usia Dini. ThufuLA: Jurnal Inovasi Pendidikan Guru Raudhatul Athfal, 5(2), 267. https:// doi.org/10.21043/thufula.v5i2.3475

Dewi, W. A. F. (2020). Dampak COVID-19 terhadap Implementasi Pembelajaran Daring di Sekolah Dasar. Edukatif: Jurnal Ilmu Pendidikan, 2(1), 55-61. https:// doi.org/10.31004/edukatif.v2i1.89

Hasanah, N. I., \& Ulya, N. (2020). Strategi Pengenalan Bahasa Inggris Pada Anak Usia Dini Di TK Santa Maria Banjarmasin. Jurnal Warna : Pendidikan Dan Pembelajaran Anak Usia Dini, 5(2), 57-68. https://doi.org/10.24903/jw.v5i2.525

Hasfira, \& Marelda, M. (2021). Peran Guru Dalam memotivasi Siswa Pada Masa Pandemi. Jurnal Pendidikan Dan Konseling, 3(1), 80-84. https://doi.org/10.31004/jpdk.v3i1.1430 
DOI: 10.31004/obsesi.v4i4.1916

Hewi, L., \& Asnawati, L. (2020). Strategi Pendidik Anak Usia Dini Era Covid-19 dalam Menumbuhkan Kemampuan Berfikir Logis. Jurnal Obsesi : Jurnal Pendidikan Anak Usia Dini, 5(1), 158. https://doi.org/10.31004/obsesi.v5i1.530

Hignasari, L. V. (2020). Analisis Peluang Usaha Pembuatan Alat Permainan Edukatif Anak Selama Masa Pandemi Covid-19. Jurnal Ilmiah Vastuwidya, 3(2), 14-22. https://doi.org/10.47532/jiv.v3i2.209

Huda, K., Munastiwi, E., Glasser, J. P., \& Pendahuluan, A. (2020). Bakat Dan Kreativitas Di Era Pandemi Covid-19. 80-87. https:// doi.org/10.32529/glasser.v4i2.670

Kurniawan, H. \&, \& Hermawan, R. (2016). Program Parenting untuk Membentuk Karakter Anak Usia Dini di Lembaga PIAUD. Jurnal PGRA, 1(1), 29-39.

Mufaziah, E., \& Fauziah, P. (2020). Kendala Orang Tua dalam Mendidik Anak Usia Dini pada Saat Pandemi Covid 19. Jurnal Obsesi : Jurnal Pendidikan Anak Usia Dini, 5(2), 10451051. https:// doi.org/10.31004/obsesi.v5i2.746

Mutiani, R., \& Suyadi. (2020). Diagnosa Diskalkulia Generasi Alpha: Masalah dan Perkembangannya. Edumaspul: Jurnal Pendidikan, 4(1), 104-112. https://doi.org/10.33487/edumaspul.v4i1.278

Nurul Fadlilah, A., Sylviarini Suryawidarti, M., Sunan Kalijaga Yogyakarta -Jl Marsda Adisucipto, U., Yogyakarta, D., Rumah Cerdas Malang -Jl Ikan Tombro, K., \& Malang, K. (2021). Strategi Reward and Punishment Untuk Meningkatkan Kedisiplinan Guru Paud. JAMP: Jurnal Adminitrasi Dan Manajemen Pendidikan, 4(1), 88-94. https://doi.org/10.17977/um027v4i12021p88

Oktaria, R., \& Putra, P. (2020). Pendidikan Anak Dalam Keluarga Sebagai Strategi Pendidikan Anak Usia Dini Saat Pandemi Covid-19 Child Education In The Family As An Early Childhood. 7(1), 41-51. https:// doi.org/10.24036/108806

Pagarwati, L. D. A., \& Rohman, A. (2020). Grandparenting Membentuk Karakter Anak Usia Dini di Masa Pandemi Covid-19. Jurnal Obsesi : Jurnal Pendidikan Anak Usia Dini, 5(2), 1229-1239. https://doi.org/10.31004/obsesi.v5i2.831

Pangastuti, R., Pratiwi, F., Fahyuni, A., Al, R. A., Kamal, A., \& Madura, B. (2020). Pengaruh Pendampingan Orangtua Terhadap Kemandirian dan Tanggung Jawab Anak Selama Belajar dari Rumah. 2(2), 132-146. https:// doi.org/10.15642/jeced.v2i2.727

Qadafi, M. (2020). Pembelajaran Bahasa Inggris pada Anak di Sangkhom Islam Wittaya School saat Pandemi Covid-19. Jurnal Obsesi : Jurnal Pendidikan Anak Usia Dini, 5(1), 422. https://doi.org/10.31004/obsesi.v5i1.591

Rozie, F., Safitri, D., Haryani, W., \& Samarinda, U. M. (2019). Peran Guru Dalam Penanganan Perilaku Anak Hiperaktif Di TK Negeri 1 Samarinda. 1(2), 53-59. https://doi.org/10.15408/jece.v1i2.12874

Sabaniah, S., Ramdhan, D. F., \& Rohmah, S. K. (2021). Peran Guru dalam Pelaksanaan Pembelajaran Jarak Jauh di Tengah Wabah Covid - 19. Edunesia: Jurnal Ilmiah Pendidikan, 2(1), 43-54. https://doi.org/10.51276/edu.v2i1.77

Satrianingrum, A. P., Prasetyo, I., Anak, P., Dini, U., \& Yogyakarta, U. N. (2021). Jurnal Obsesi : Jurnal Pendidikan Anak Usia Dini Persepsi Guru Dampak Pandemi Covid-19 terhadap Pelaksanaan Pembelajaran Daring di PAUD Abstrak. 5(1), 633-640. https://doi.org/10.31004/obsesi.v5i1.574

Tiolina Siregar, H., \& Tarigan, R. M. (2021). Efektivitas Pembelajaran Daring Dengan Menggunakan Google Classroom (Gcr) Pada Mata Kuliah Konsep Dasar Ipa 
Mahasiswa Pgsd. Journal of Natural Sciences, 1(3), 136-142. https://doi.org/10.34007/jns.v1i3.24

Ulfa, M., \& Na'imah, N. (2020). Peran Keluarga dalam Konsep Psikologi Perkembangan Anak Usia Dini. Aulad: Journal on Early Childhood, 3(1). https:// doi.org/10.31004/aulad.v3i1.45

Umi, G., Karmila, M., Guru, P., Anak, P., \& Dini, U. (2020). Pendidikan Keterampilan Hidup ( Life Skill ) Anak Usia Dini Selama Masa Pandemi Covid-19. https://doi.org/10.26858/tematik.v6i2.15473

Wakhidah, E. W., \& Umah, F. M. (2020). Penerapan Video Pembelajaran Daring Anak Usia Dini Pada Masa Pandemi Covid-19 pertama kali di Indonesia, 3(2), 140-160. https://doi.org/10.24042/ajipaud.v3i2.7315

Windarsih, C. A., Jumiatin, D., Efrizal, E., Sumini, N., \& Utami, L. O. (2017). Implementasi Pendidikan Anak Usia Dini Inklusif Dikota Cimahi Jawa Barat. P2M STKIP Siliwangi, 4(2), 7. https://doi.org/10.22460/p2m.v4i2p7-11.636

Wiresti, R. D. (2020). Aulad: Journal on Early Childhood Aspek Perkembangan Anak: Urgensitas Ditinjau dalam Paradigma Psikologi Perkembangan Anak. 3(1), 36-43. https://doi.org/10.31004/aulad.v3i1.53

Zahroh, S., \& Na'imah, N. (2020). Peran Lingkungan Sosial terhadap Pembentukan Karakter Anak Usia Dini di Jogja Green School. Jurnal PG-PAUD Trunojoyo : Jurnal Pendidikan $\begin{array}{lllll}\text { Dan Pembelajaran Anak } & \text { Usia }\end{array}$ https:// doi.org/10.21107/pgpaudtrunojoyo.v7i1.6293 